\title{
Tetracycline marking of coregonids at the time of egg fertilization
}

\author{
Ch. Ruhlé ${ }^{1}$ and C. Winecki-Kühn ${ }^{2}$ \\ 1 Fish and wildlife service of the Canton of St. Gallen, Burggraben 26, CH-9001 St. Gallen, \\ Switzerland \\ ${ }_{2}^{2}$ Former address: C. Grieder, Lake Research Laboratory EAWAG/ETH, CH-6047 Kastanien- \\ baum, Switzerland
}

Key words: tetracycline; marking; coregonids; recruits; reproduction; stocking.

\begin{abstract}
Tetracycline marking of otoliths can be achieved by osmotic importation at fertilization when hardening is conducted in tetracycline solutions. Marks produced are recognizable even in fish of catchable size without a very extensive otolith preparation. The method can contribute to estimations of stocking efficiency and to discern recruits of natural and artificial reproduction.
\end{abstract}

\section{Introduction}

Since 1852, when the first hatchery was built in Switzerland for the incubation of Arctic char eggs (Wanger, 1896) stock-enhancement by stocking has become a management tool of increasing importance: nowadays 157 hatcheries (one per $260 \mathrm{~km}^{2}$ !) produce 700 million fry and 25 million fingerlings and yearlings (BUWAL). Most of the fry stocked are coregonids (95\%) incubated in 44 hatcheries.

For several decades, stocking was justified by the heavy human impact altering the conditions for natural reproduction. In recent years it has, however, been possible to halt or even to reverse the eutrophication process in several lakes. Nevertheless, the well-established measures for enhancing the stocks have not yet been abandoned. Considering that about $50 \%$ of the coregonids caught in the spawning fishery are not ripe, and assuming favourable conditions for natural reproduction, it has to be concluded that continued stocking could lead to a contraproductive reduction of the reproductive potential and weaken the stocks.

Although the validation of stocking efficiency has hardly ever been tried (Müller, 1990), abandoning the stocking programs is obviously feasible only if the efficiency of natural reproduction is evident.

Model estimations (Todd, 1986; Pedroli, 1986; Hartmann, 1986, 1987; Eckmann et al., 1988) as well as in-situ tests for successful natural reproduction (Müller, in press) have so far not been able to eliminate former doubts (Hartmann, 1989; 
Eckmann and Gaedke, 1989). Cessation of stocking to demonstrate the efficiency of natural reproduction is considered to be too risky and has consequently not been taken into consideration. Marking experiments with external tags can only be made with large fish, and internal tags, e.g. coded wire, are applicable only to coregonids of at least $50 \mathrm{~mm}$ (Meng et al., 1986). Due to the lack of information on natural mortality occuring between the fry stage and the age of externally or internally tagged fish (fingerlings or bigger), estimations of the stocking value of these larger fish cannot be transposed to the fry usually stocked. For these reasons, a marking method for eggs and fry applying biotags or chemicals (Ruhlé and Grieder 1989) must be used.

The antibiotic tetracycline, when introduced into the body of fish or other vertebrates, is known to produce marks on bony structures, e.g. otoliths or scales, recognizable when observed under fluorescent light. In other experiments (Weber and Ridgway, 1962, 1967; Meunier, 1972, 1974; Meunier and Boivin, 1972, 1978; Nagiec and Nagiec, 1988) the marking substance was introduced by injection or with food. The injection method, however, cannot be applied to small fish, and the ingestion method is problematic since food intake may be irregular or living fooditems difficult to infuse with tetracycline. The exposition of larvae and fry to tetracycline solutions (Dabrowski and Tsukamoto, 1986) leads to low and irregular marking frequencies and requires a lot of tetracycline when mass-markings are made.

Since 1979 we have consequently attempted to design a different concept for tetracycline incorporation and marking (Ruhlé and Grieder, 1989): we assume that the water needed for hardening of artificially fertilized salmonid eggs is a transportation medium for the tetracycline that is supposed to maintain its marking ability during storage in the yolk liquid and act as marking substance when calcification begins. Scientists informed about our experiments predicted this concept to be unavailing. Initial experiments conducted with coregonids were therefore suspended for several years. However, experiments with brown trout (Salmo trutta) and rainbow trout (Oncorhynchus mykiss) eggs indicate that the method functions in principle (Ruhlé and Grieder, 1989). The present paper discusses its applicability to coregonids.

\section{Materials and Methods}

In three experiments conducted between 1979 and 1990 (Table 1) eggs and milt (obtained from Lake Constance Blaufelchen Coregonus lavaretus, wiped dry before stripping) were well mixed and immediately poured in tetracycline (tetracyclinehydro-chloride $\mathrm{C}_{22} \mathrm{H}_{24} \mathrm{~N}_{2} \mathrm{O}_{8} \mathrm{HCL}$ purum Fluka $98 \%$ ) solutions of different concentration where hardening took place. In another experiment, Blaufelchen fry were exposed to a tetracycline solution.

In experiment 1, conducted in 1979/80 as a feasibility study, tetracycline solutions of a very large concentration range were applied (Table 1). The concentration of the solutions applied in later experiments ( 2 and 4 ) already considered the results of this first experiment. 
Table 1. Marking experiments with coregonids

\begin{tabular}{|c|c|c|c|c|c|}
\hline $\begin{array}{l}\text { Expcriment } \\
\text { No. }\end{array}$ & $\begin{array}{l}\text { Time of } \\
\text { elaboration }\end{array}$ & Method applied & $\begin{array}{l}\text { Tetracycline solutions applied } \\
\text { (concentrations } \mathrm{mg} \cdot \mathrm{1}^{-1} \text { ) }\end{array}$ & $\begin{array}{l}\text { Goal of } \\
\text { experiment }\end{array}$ & $\begin{array}{l}\text { Rearing duration } \\
\text { (maximum age } \\
\text { of fish examined) }\end{array}$ \\
\hline 1 & $1979 / 80$ & $\begin{array}{l}\text { osmotic } \\
\text { incorporation } \\
\text { at fertilization }\end{array}$ & $\begin{array}{l}1000,200,100 \\
20,10,2\end{array}$ & feasibility study & fry \\
\hline 2 & $1987 / 90$ & $\begin{array}{l}\text { osmotic } \\
\text { incorporation } \\
\text { at fertilization }\end{array}$ & 2000,1500 & $\begin{array}{l}\text { long-time study for } \\
\text { mark-recognition }\end{array}$ & $2+$ \\
\hline 3 & 1988 & exposure of fry & 600 & $\begin{array}{l}\text { comparison of } \\
\text { methods (mortality) }\end{array}$ & fry \\
\hline 4 & $1989 / 90$ & $\begin{array}{l}\text { osmotic } \\
\text { incorporation } \\
\text { at fertilization }\end{array}$ & $\begin{array}{l}2000,1900,1800 \\
1700,1600,1500\end{array}$ & $\begin{array}{l}\text { determination } \\
\text { of mortality rates }\end{array}$ & fry \\
\hline
\end{tabular}


After an exposure of one hour the eggs were washed and placed in incubation jars (61 in experiment 1 and 2,11 in experiment 4). Temperature of the incubation water ranged from 1.5 to $2^{\circ} \mathrm{C}$ in experiment 1 and 2 and from 6 to $7^{\circ} \mathrm{C}$ in experiment 4 . In experiment 1 and 2 incubation took place in obscurity; the incubation jars of experiment 4 were exposed to day-light. During or at the end of incubation, mortality was recorded.

According to the different goals (feasibility study; long-time study for mark recognition in larger fish; experiment to determine concentration-dependent mortality differences during incubation), the fish of the three experiments applying this marking method (experiments 1,2 and 4) were reared for different time periods (Table 1).

Fry of experiment 1 were kept frozen from 1980 to 1987 before any further treatment was done.

The otoliths (sagittae and asterisci) were examined for tetracycline markings. In fry and very small fish fed during a short period only, otoliths could be recognized in the body-mass mashed between two glass slides and removed. Otoliths of larger fish had to be sectioned out. They were dried and mounted on glass slides in a drop of Powabond 102 (cyanoacrylate contact glue, Double H International Ldt., Staines, Middlesex TW18 4XQ). A first microscopical check showed whether the center of the otolith was visible or not. If it was visible, the examination continued under fluorescent light; if not, the thickness of the otolith was reduced by grinding with wet abrasive paper P 600 until the center was visible. The dried otoliths were mounted in Entellan and covered with a glass cover slide. For the check for markings, a Zeiss Standard microscope with phase-contrast and reflected light fluorescence with blue excitation was used (filter BP 450-490, FT 510, barrier filter LP 520, objectives $10 \times$ or $20 \times$ ). Under this configuration, otoliths appeared light yellow and tetracycline marks orange.

For comparison, in particular concerning mortalities, free-swimming fry were also marked in circulation tanks applying the method described by Dabrowski and Tsukamoto (1986) (experiment 3).

\section{Results}

\section{Experiment 1}

Mortality was recorded at the end of the incubation period only. It ranged from 15 to $25 \%$ for all concentrations applied and is comparable to that observed in controls. For the reasons mentioned in the introduction, the fry obtained were kept frozen until 1987. By that time, experiment 2 with more promising concentrations had already been started (Ruhlé and Grieder, 1989). Therefore, the otoliths of only 10 specimens (fry) from the 1000 and the $200 \mathrm{mg} \cdot 1^{-1}$ samples were examined. In the four otoliths (asterisci and sagittae) of all specimens from the $1000 \mathrm{mg} \cdot \mathrm{l}^{-1}$ sample, tetrycycline marks were visible. They could not be seen in the otoliths of specimens from the $200 \mathrm{mg} \cdot 1^{-1}$ sample. In consideration of the results obtained 
in the brown trout and rainbow trout experiments, specimens exposed to less concentrated tetracycline solutions $\left(100 \mathrm{mg} \cdot 1^{-1}\right.$ and lower $)$ were not examined.

\section{Experiment 2}

Mortality up to the end of the incubation period was $19 \%$ for the $1500 \mathrm{mg} \cdot \mathrm{l}^{-1}$ sample and $35 \%$ for the $2000 \mathrm{mg} \cdot 1^{-1}$ sample. Obviously, mortality is concentrationdependent. Peak mortality in the $2000 \mathrm{mg} \cdot 1^{-1}$ sample occured during hatching. The results of the otolith examination are summarized in Table 2 . They indicate that the otolith examination method applied is successful for fish from the $1500 \mathrm{mg} \cdot 1^{-1}$ sample up to a size of about $75 \mathrm{~mm}$ and for fish from the $2000 \mathrm{mg} \cdot \mathrm{1}^{-1}$ sample up to a size $>150 \mathrm{~mm}$. Otoliths with a fluorescent mark in the center are shown in Fig. 1.

\section{Experiment 3}

Experiment 3 was aimed at assessing the mortality of free-swimming fry when exposed to tetracycline solutions (Dabrowski and Tsukamoto, 1986). The mortality observed $(<1 \%)$ during the one-day exposure of fry to a $600 \mathrm{mg} \cdot 1^{-1}$ tetracycline solution is comparable to that of controls in circular tanks. The recirculated and aired solution became foamy during a one-day treatment and could not be utilized a second time. The check for tetracycline marks in the otoliths of the mashed fry failed in most cases. More accurate otolith preparation and analysis were not attempted.

\section{Experiment 4}

Experiment 2 indicated that with the otolith preparation technique described, mark detection is possible in fish of 75 to $>150 \mathrm{~mm}$ if tetracycline solutions of 1.5 to $2.0 \mathrm{~g} \cdot 1^{-1}$ are used. The mortality rates observed in the samples treated in 5 solutions of concentrations between 1.5 and $2 \mathrm{~g} \cdot \mathrm{l}^{-1}$ point to a positive mortalityconcentration correlation (Fig. 2). Total mortality from fertilization to hatching is $35 \%$ for the control. This mortality rate is influenced by the particular incubation method applied and exceeds the one observed in experiment 1 and 2 (cold water; obscurity) by about $15 \%$. It ranged between $67 \%$ at $1.5 \mathrm{~g} \cdot \mathrm{l}^{-1}$ and $81 \%$ at $2.0 \mathrm{~g} \cdot \mathrm{l}^{-1}$ or between $38 \%$ and $46 \%$ when related to samples incubated with the modalities of experiment 1 and 2.

\section{Discussion}

At the beginning of the experiments in 1979, the concept of importing tetracycline as a marking substance into artificially fertilized salmonid eggs by osmotic incorporation during the hardening process was under debate. A first check for tetracycline marks on scale nuclei of specimens from experiment 1 gave negative results, but the 
Table 2. Results of otolith examination of fish of different ages in experiment 2. Date of fertilization and marking: 10-12-1987; date of hatching: 3-31988 .

+ otoliths with marks, - otoliths without marks

\begin{tabular}{|c|c|c|c|c|c|c|c|}
\hline \multirow{2}{*}{$\begin{array}{l}\text { Date } \\
\text { of sampling } \\
\text { age of fish } \\
\text { examined }\end{array}$} & \multirow[t]{2}{*}{$\begin{array}{l}\text { Length of } \\
\text { fish examined }\end{array}$} & \multicolumn{2}{|c|}{$\begin{array}{l}2000 \mathrm{mg} \cdot 1^{-1} \\
\text { tetracycline solution }\end{array}$} & \multicolumn{2}{|c|}{$\begin{array}{l}1500 \mathrm{mg} \cdot 1^{-1} \\
\text { tetracycline solution }\end{array}$} & \multicolumn{2}{|c|}{$\begin{array}{l}\text { Control (no tetracycline } \\
\text { added to hardening water) }\end{array}$} \\
\hline & & $\begin{array}{l}\text { No. of } \\
\text { fish examined }\end{array}$ & Results & $\begin{array}{l}\text { No. of } \\
\text { fish examined }\end{array}$ & Results & $\begin{array}{l}\text { No. of } \\
\text { fish examined }\end{array}$ & Results \\
\hline $\begin{array}{l}22-4-88 \\
\sim 2 \text { months }\end{array}$ & & 10 & all + & & & & \\
\hline $\begin{array}{l}28-6-88 \\
\sim 4 \text { months }\end{array}$ & & 10 & all + & 11 & $\mathrm{all}+$ & 10 & all- \\
\hline $\begin{array}{l}29.8-88 \\
\sim 6 \text { months }\end{array}$ & & 10 & all + & 7 & all + & 6 & all - \\
\hline $\begin{array}{l}9-1-89 \\
\sim 11 \text { months }\end{array}$ & $84-102 \mathrm{~mm}$ & 10 & all + & 10 & $\begin{array}{l}9+; 1-(2 / 2 ; 2 / 2 ; \\
2 / 2 ; 2 / 2 ; 2 / 2 ; 0 / 2 ; \\
0 / 2 ; 2 / 0 ; 2 / 0 ; 0 / 0) *\end{array}$ & & \\
\hline $\begin{array}{l}13-3-89 \\
\sim 13 \text { months }\end{array}$ & & 3 & all + & & & & \\
\hline $\begin{array}{l}5-10-89 \\
\sim 20 \text { months }\end{array}$ & & 10 & $8+; 2-$ & & & & \\
\hline $\begin{array}{l}25-1-90 \\
\sim 23 \text { months }\end{array}$ & $132-160 \mathrm{~mm}$ & 10 & $\begin{array}{l}\text { all }+(1 / 1 ; 1 / 1 ; \\
1 / 2 ; 2 / 2 ; 2 / 2 ; 1 / 2 ; \\
2 / 2 ; 0 / 1 ; 2 / 2 ; 0 / 2)^{*}\end{array}$ & & & & \\
\hline
\end{tabular}

* Meaning of expressions in brackets: $1 / 2$ detection of marks on 1 sagitta and on both asterisci, etc. 

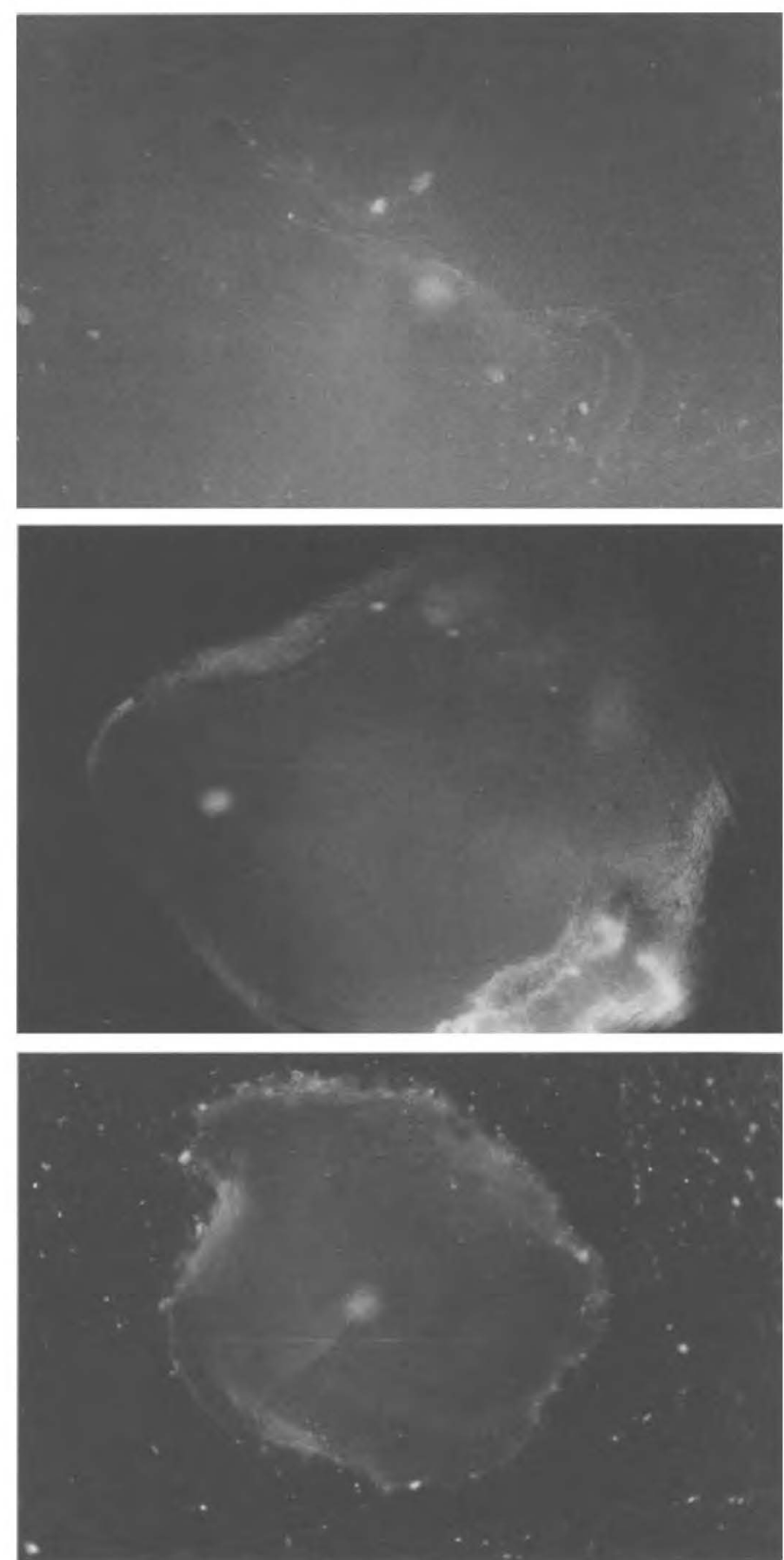

Figure 1. Photomicrographs of otoliths of two years old coregonids from experiment 2. Date of marking 10-12-1987, date of sampling 25-1-1990, tetracycline concentration $2000 \mathrm{mg} \cdot 1^{-1}$ (see Table 2). The fluorescent marks in the nuclei are well recognizable.

Above: sagitta of a $143 \mathrm{~mm}$ fish

Center: asteriscus of a $120 \mathrm{~mm}$ fish

Below: asteriscus of a $150 \mathrm{~mm}$ fish 


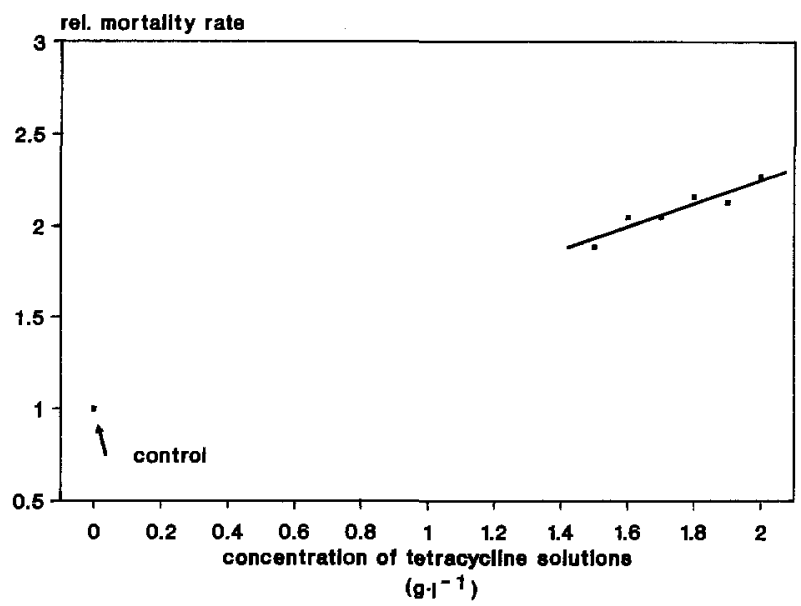

Figure 2. Relative mortality rates observed during incubation and hatching in egg samples of experiment 4 marked at the time of egg fertilization by tetracycline solutions of different concentrations (mortality rate in non-marked controls $=1$ )

samples remained frozen for further studies. New examinations involving otoliths were carried out on the basis of results published by Schmitt (1984) and Dabrowski and Tsukamoto (1986).

Beside coregonid eggs, those from brown trout and rainbow trout were included in our early experiments. Assuming that larger amounts of marking substance is stored in larger yolk masses, which would increase the probability of staining the bony organs formed during the early life history (Nagiec and Nagiec, 1983), trout otoliths were examined first. The results (Ruhlé and Grieder, 1989) indicated that the concept works. It also became clear that the utilization of tetracycline solutions of concentrations below $1000 \mathrm{mg} \cdot 1^{-1}$ would not produce marks easily recognizable without extensive otolith preparation. Therefore, and because experiment 2 was already under way, examination of material from experiment 1 was restricted to some few specimens from the 1000 and $200 \mathrm{mg} \cdot 1^{-1}$ samples. The results obtained indicated that the concept tested with trouts works also with coregonids: tetracycline solutions of the right concentration can be used to replace water in the hardening process without harmful effects on sperm and egg.

Tetracycline osmotically imported into the egg during hardening maintains its capacity to be incorporated in the bony organs formed during embryogenesis. It can be detected when observed in fluorescent light. All tetracycline stored in the yolk liquid becomes completely incorporated already at the beginning of otolith formation. Detected marks thus correspond to otolith nuclei. No tetracycline is available to be deposited on scale nuclei formed later than otolith nuclei. Therefore, the search for tetracycline marks on scales at the beginning of this study must have failed.

The results of experiment 2 show that $2000 \mathrm{mg} \cdot 1^{-1}$ solutions cause higher mortalities than $1500 \mathrm{mg} \cdot 1^{-1}$ solutions, thus confirming the results obtained in trout 
experiments (Ruhlé and Grieder, 1989). The concentration-dependent differences in mortality already showed up during incubation and hatching. Experiment 2 does not include any samples treated in solutions of low concentration which have pointed to a tetracycline-induced mortality reduction in trout experiments when compared to non-treated samples. Such reductions have also been observed by Tsukamoto (1985) and, for coregonids, by Dabrowski and Tsukamoto (1986).

In coregonids $>100 \mathrm{~mm}$, detection of marks is far easier when $2000 \mathrm{mg} \cdot 1^{-1}$ solutions are used instead of weaker solutions. Otoliths of coregonids of this size have to be ground and the probability of grinding off the marked nucleus and of erroneously recording the specimen checked as non-marked (" - " in Table 2) is much higher when $1500 \mathrm{mg} \cdot 1^{-1}$ solutions are used. In this respect, tetracycline marking by osmotic incorporation at fertilization using low concentrated solutions has disadvantages found also in the exposure method (Dabrowski and Tsukamoto, 1986). In fish marked by this method, tetracycline is incorporated in the thin otolith layer formed within the exposure period. Ruhlé and Grieder (1989) have observed that in larger otoliths which need grinding for examination, the thin fluorescent layer may be unintentionally ground off, leading to erroneous negative results. In the experiments by Dabrowski and Tsukamoto (1986), the examination of otoliths took place only 87 days after exposure to tetracycline even for the oldest specimens. The poor fish growth and otolith increment accomplished in this short period allows the detection of thin tetracycline marks without otolith size reduction. In larger (catchable) fish, in particular if a distinction between natural and artificial recruits is to be made, mark detection without otolith size reduction will fail. Long-term or multiple exposure could reduce this disadvantage. Such a marking procedure, however, is very expensive. A one-day exposure in recirculated $600 \mathrm{mg} \cdot 1^{-1}$ solutions in circulation tanks stocked with 200,000 to 500,000 fry needs 50 to 20 times more marking substance than the marking of the same number of fish by osmotic incorporation at fertilization. Under run-through conditions recommended because of the poor stability of tetracycline solutions in circular tanks, this factor increases to 700 and long-term or multiple exposure would raise it further. Considering mortalities, the exposure method (experiment 3 ) is obviously less problematic than the incorporation at fertilization method.

Figure 2, representing the results of experiment 4, indicates that good recognition of marks (implying solutions of rather high concentration; see experiment 2) and low mortality rates are difficult to reconcile: tetracycline marks visible even in larger fish without a too extensive preparation of otoliths may - at least so far-only be achieved at the expense of increased mortalities during incubation and hatching. New experiments already under way will show whether shorter treatments in $2000 \mathrm{mg} \cdot 1^{-1}$ solutions during hardening (10 to $50 \mathrm{~min}$ ) can reduce mortality without impairing the recognition of marks in otoliths. On the other hand, new methods, e.g. chemical analysis for the recognition of tetracycline incorporated in otoliths of large fish treated by the incorporation method should be tested.

In spite of high mortalities occurring during incubation and hatching, tetracycline marking of coregonids by osmotic incorporation at fertilization is a valuable tool for estimating the efficiency of fry stockings. Since the marks produced in nearly all fish can be recognized also in fish of catchable size, mass-marking applying this method 
may help to assess the utility of hatchery operations and to eliminate doubts regarding model estimations.

\section{Summary}

Water used for hardening artificially fertilized coregonid eggs can be replaced by tetracycline solutions. Tetracycline imported osmotically maintains the capacity to be incorporated in calcified structures during embryogenesis. Incorporation occurs during the beginning of otolith formation. Marks formed can be recognized if examined in fluorescent light. A solution of $2000 \mathrm{mg} \cdot 1^{-1}$ produces marks recognizable in fish larger than $100 \mathrm{~mm}$ without very extensive preparation of otoliths. During incubation and hatching, high mortality rates occur due to the application of $2000 \mathrm{mg} \cdot 1^{-1}$ solutions. Considering the advantages when marks have to be detected in otoliths of larger or even catchable fish, osmotic incorporation of tetracycline at fertilization is jugded to be a better method for mass-marking of coregonids than the exposure of fry to tetracycline solutions.

\section{ACKNOWLEDGEMENTS}

We thank $\mathrm{O}$. Trunz and F. Fehr for the work done in the hatchery and the anonymous reviewers for their helpful comments. This publication terminates the scientific activities of Mrs. C. WineckiKühn, whom the first named author thanks for long-lasting and great cooperation.

\section{REFERENCES}

BUWAL: Jährlicher Bericht über die in der Schweiz eingesetzten Fische. Bundesamt für Umwelt, Wald und Landschaft, Bern, 1980-1990.

Dabrowski, K. and K. Tsukamoto, 1986. Tetracycline tagging in coregonid embryos and larvae. J. Fish Biol. 29:691-698.

Eckmann R., U. Gaedke and H. J. Wetzlar, 1988. Effects of climatic and density-dependent factors on year class strength of Coregonus lavaretus in Lake Constance. Can. J. Fish. Aquat. Sci. 45:1088-1093.

Eckmann, R. and U. Gaedke, 1989. Response to Hartmann's "Is recruitment of the whitefish (Coregonus lavaretus) of Lake Constance already understood?" Can. J. Fish. Aquat. Sci. 46:726-727.

Hartmann, J., 1986. Besatzerfolg. Der Fischwirt 36:22-35.

Hartmann, J., 1987. Whitefish as indicators of cultural eutrophication? Schweiz. Z. Hydrol. $49(3): 341-352$.

Hartmann, J., 1989. Is recruitement of the whitefish (Coregonus lavaretus) of Lake Constance already understood? Can. J. Fish. Aquat. Sci. 46:725-726.

Meng, H. J., R. Müller and W. Geiger, 1986. Growth, mortality and yield of stocked coregonid fingerlings identified by microtags. Arch. Hydrobiol. Beih. 22:319-325.

Meunier, F., 1972. Marquages simples et multiples du tissu osseux de quelques Téléostéens par des substances fluorescentes. C. R. Acad. Sc. Paris 275:1685-1688.

Meunier, F., 1974. La technique de marquage vital des tissus squelettiques des poissons. Bull. Fr. Piscic. 225:52-57.

Meunier, F. et G. Boivin, 1972. Marquages multiples du tissu osseux de quelques Téléostéens à l'aide de plusieurs fluorochromes. Bull. Soc. Zool. France 97 (3):539-540. 
Meunier, F. et G. Boivin, 1978. Action de la fluorescéine, de l'alizarine, du bleu de calcéine et de diverses doses de tétracycline sur la croissance de la truite et de la carpe. Ann. Biol. Anim. Biochem. Biophys. $18(6): 1293-1308$.

Müller, R., 1990. Management practices for lake fisheries in Switzerland. In: W. L. T. van Densen, B. Steinmetz and R.H. Hughes (Eds.). Management of freshwater fisheries. Proceedings of a symposium organized by the European Inland Fisheries Advisory Commission, Göteborg, Sweden, 31 May-3 June 1988. Pudoc. Wageningen. pp. 477-492.

Müller, R. in press. Trophic state and its implications for natural reproduction of salmonid fish. Hydrobiologia/Developments in Hydrobiology. 1992.

Nagiec, M. and C. Nagiec, 1983. Marking of juvenile whitefish coregonus lavaretus L. by tetracycline antibiotics. Rocznik Nauk Rolniczych, Seria HT 100:107-114.

Pedroli, J. C., 1986. Fluctuation in the number of fish in a cohort and possible factors determining it. Arch. Hydrobiol. Beih. 22:327-336.

Ruhlé, Ch. et C. Grieder, 1989. Nouvelle méthode de marquage vital d'oeufs de salmonidés par incorporation osmotique de tétracycline à la fécondation: Expériences préliminaires sur des oeufs de truite fario (Salmo trutta fario) et de truites arc-en-ciel (Oncorhynchus mykiss). Bull. Fr. Pêche Piscic. 315:181-188.

Schmitt, P. D., 1984. Marking growth increments in otoliths of larvae and juvenile fish by immersion in tetracycline to examine the rate of increment formation. Fish. Bull, 82:237-242.

Todd, T. N., 1986. Stocking and natural recruitment of larval coregonines in the Bodensee. Arch. Hydrobiol. Beih. 22:337-342.

Tsukamoto, K., 1985. Mass-Marking of Ayu eggs and larvae by tetracycline-tagging of otoliths. Bull, Jap. Soc. Sci. Fish. 51:903-911.

Wanger, 1896. Der Seesaibling. Schw. Fi. Ztg. 4.

Weber, D. and G. J. Ridgway, 1962. The deposition of tetracycline drugs in bones and scales of fish and its possible use for marking. Prog. Fish. Cult. 4 (24):150-155.

Weber, D. and G. J. Ridgway, 1967. Marking pacific salmon with tetracycline antibiotics. J. Fish. Res. Bd Canada 24(4):849-865.

Received 12 April 1991;

revised manuscript accepted 19 February 1992. 